مجلة الاقتصاد المنزلى ـ مجلا هب ـ العدد الأول ـ 10 ـ ب م

\section{Journal of Home \\ Economics}

http://homeEcon.menofia.edu.eg

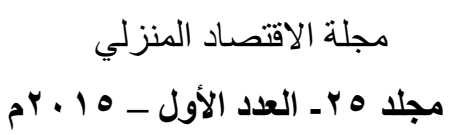

مجلة الاقتصاد المنزلي

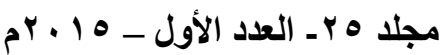

ISSN 1110-2578

\title{
الاستفادة من بقايا الاقمشة فى تصميم ملابس الاطفال
}

هانم عبدة الهوارى عحم الهوارى

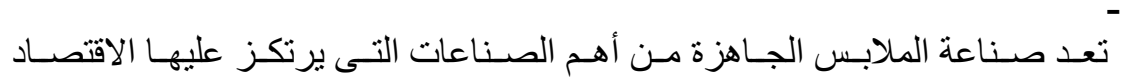

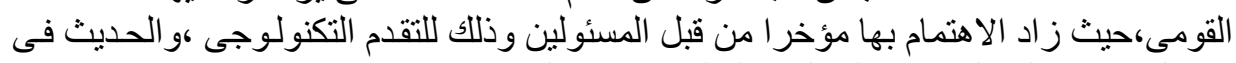

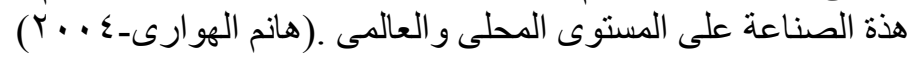

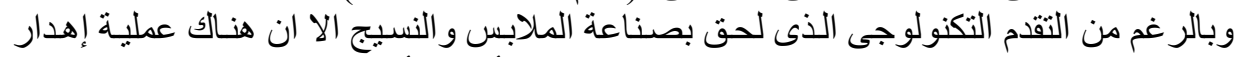

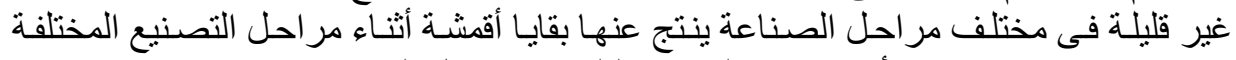

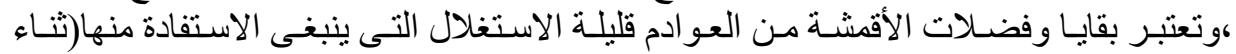

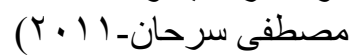

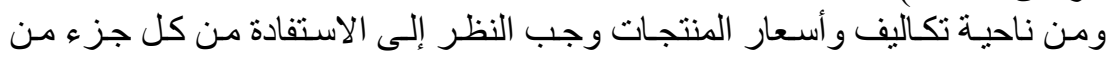

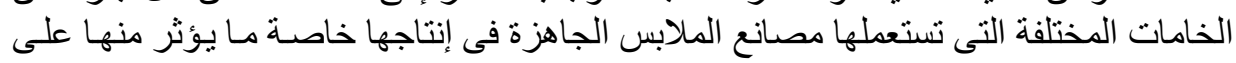

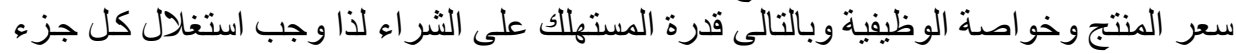

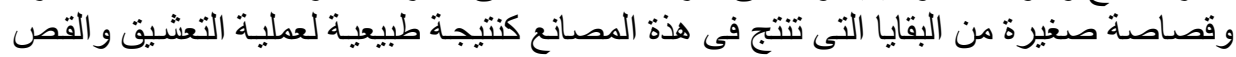

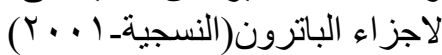

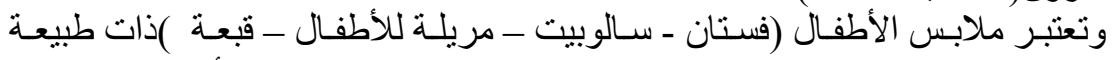

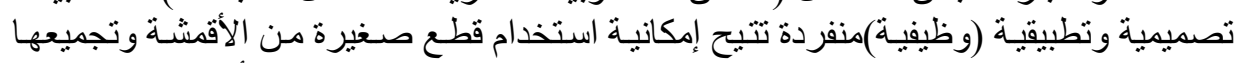

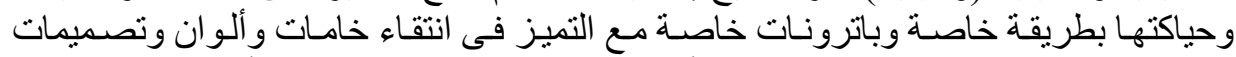

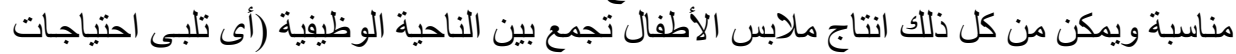

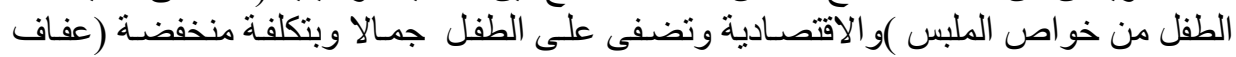

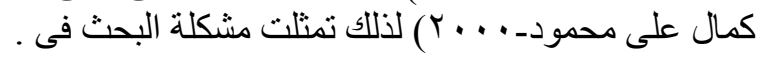

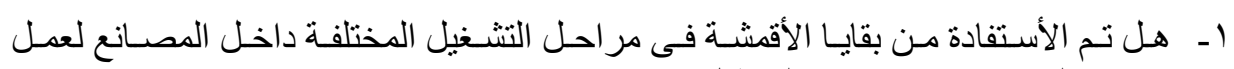

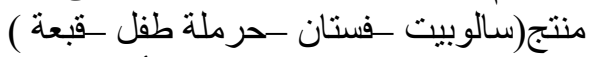

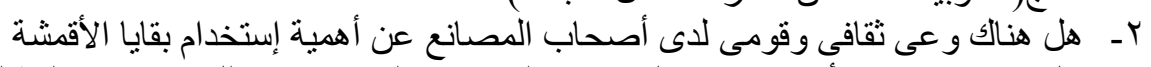

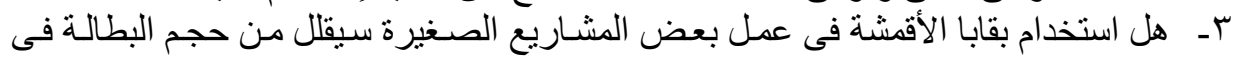
مصر ع - هل إستخدام بقايا الأقمشة سيؤثر على الجانب الجمالى و الوظيفى للمنتج

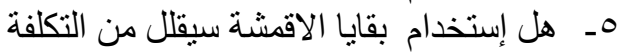




\section{مجلة الاقتصاد المنزلى ـ مجلا ه بـ العدد الأول ـ 0 1 + بم}

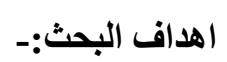

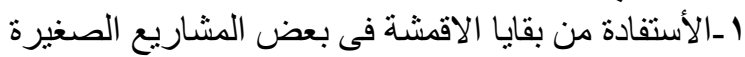

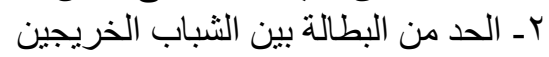

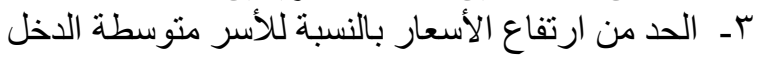

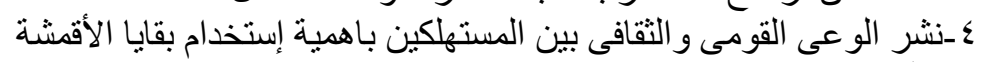

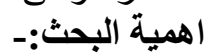

ـ الربط بين كلا من الجوانب الجمالية والوظيفية والاقتصادية للمنتج( فستان سـالوبيت -

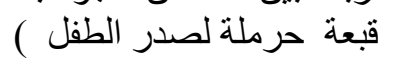

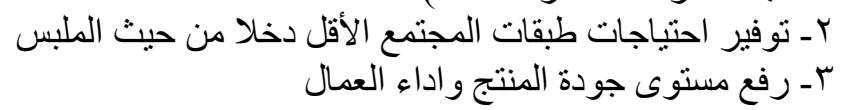
حدود البحث البحث:ث البحث:تم اجر اء الدر اسة للأطفال عمر بــاسنوات بمحافظة الغربية

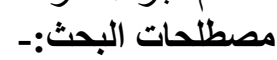

بقايا الأقمشة: هيى مخلفات وبقايا الاقمشة المتخلفة عن مصانع النسيج و الملابس بما تشملة من

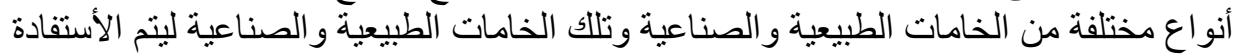

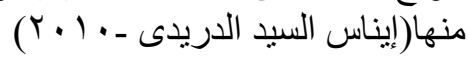

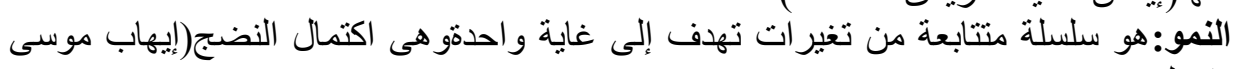

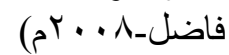
صناعة : حرفة الصانع ،وهى كل علم أو فن مارسة الأنسان حتى يمهر فنيا ويصبح حرفة

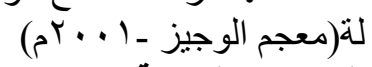
الار اسـات السابقة:- الوجيز

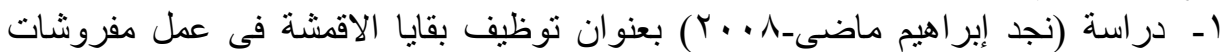

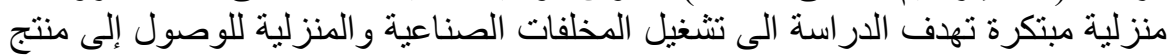

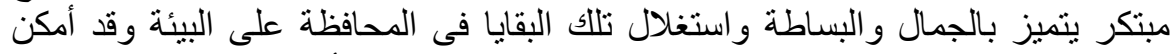

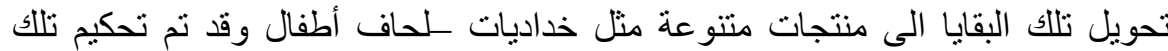

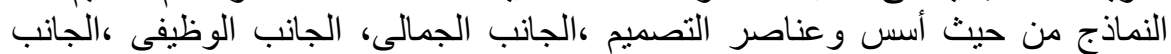

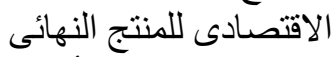

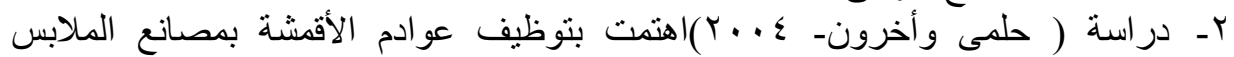

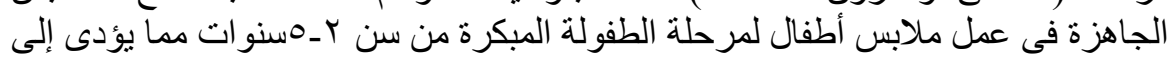

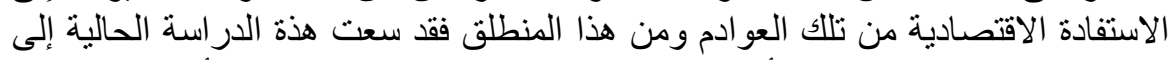
إمكانية تدوير بقايا وفضلات الأقمشة في ابتكار تصميمات جديدة لمن لملابس الأطفال

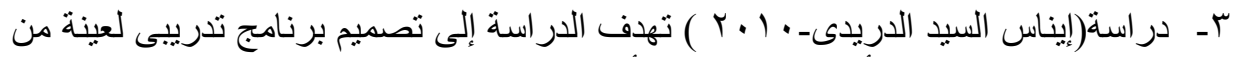

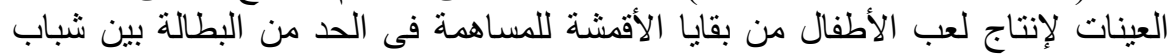

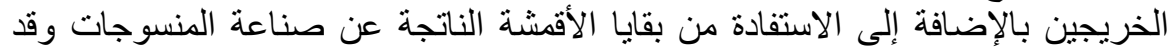
توصلت نتائج الدراسة إلى تنفيذ عدد من المنتجات التى يصلح بعضها كوسيلة تعليمية الإنة 


$$
\text { مجلة الاقتصاد المنزلى ـ مجلد ه بـ العدد الأول ـ 0 1 + rم }
$$

للأطفال من(ع ـا ) سنوات و التى صنعت من بقايا الأقشة وذللك من خلال برنامج تدريبى على مجمو عة من العن العينات

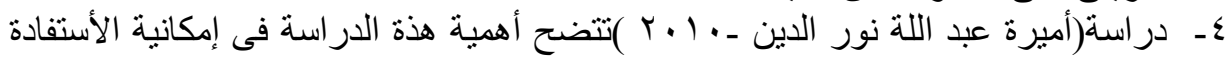

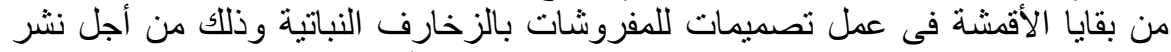

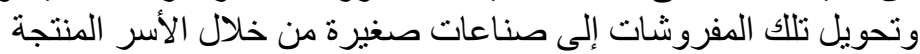

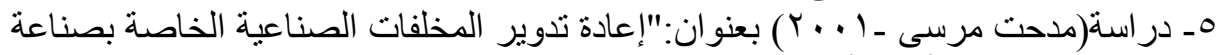

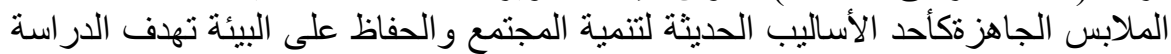

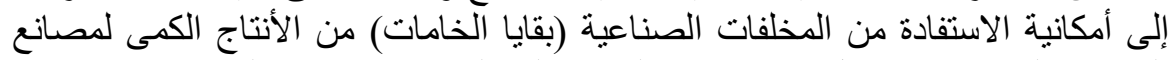

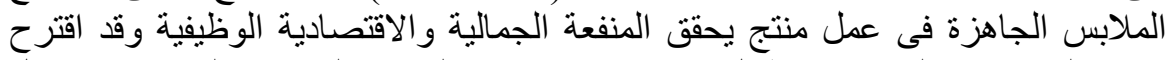

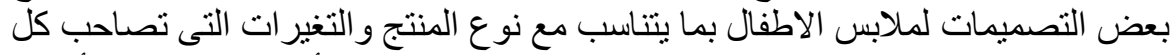

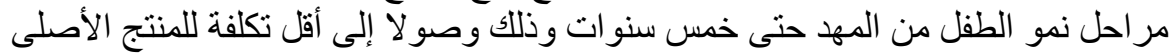
عن طريق إعادة تدوير هذة المخلفات المهن

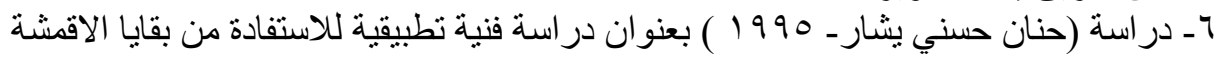

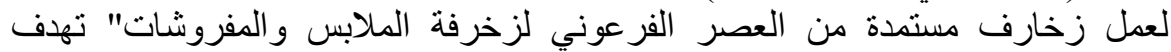

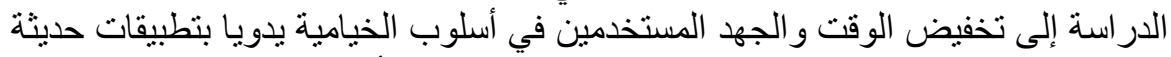

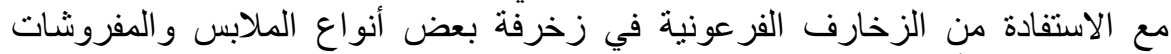
باستخدام بقايا الأقمشة. V- ـ دراسة سحر الهادي مصطفى بعنوان: "الإمكانات التشكيلية لبقايا الأقمشة و الإفادة منها في

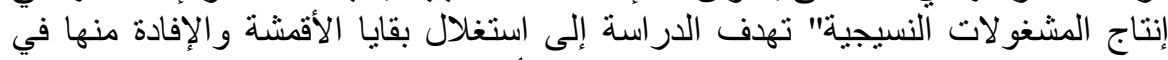

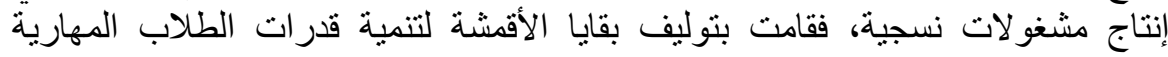
بالتجريب بخامات نسيجية غير تقليدية

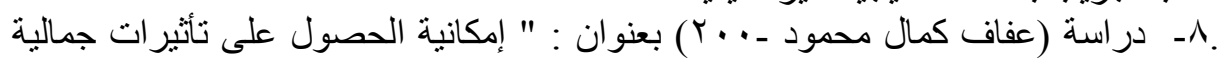

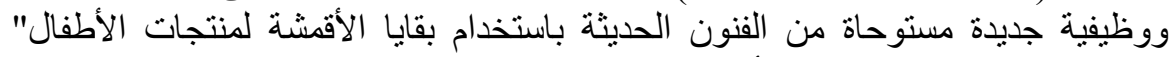

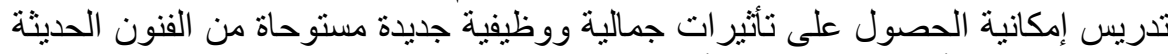

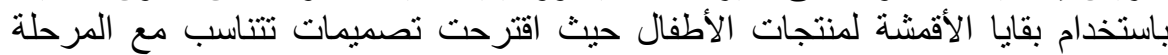

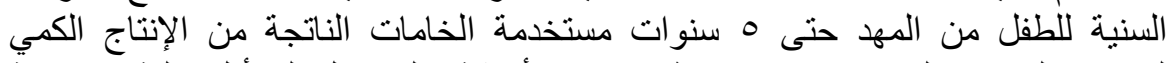

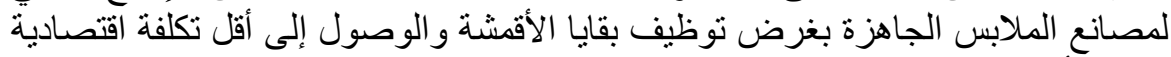

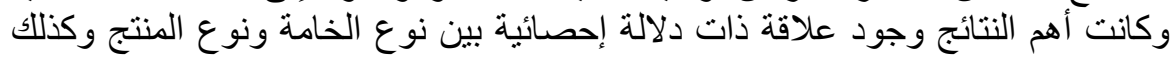

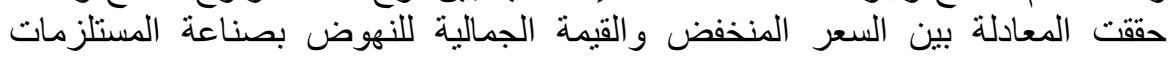

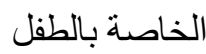

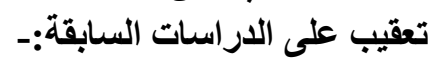

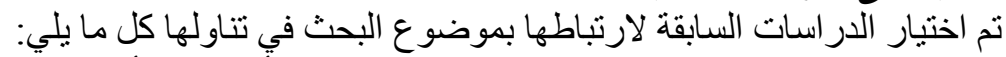

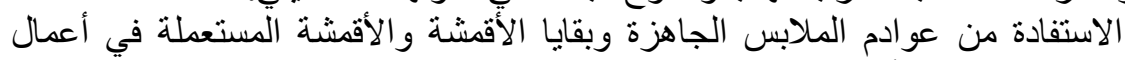

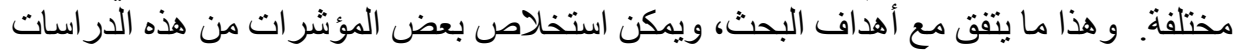

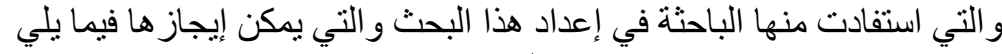

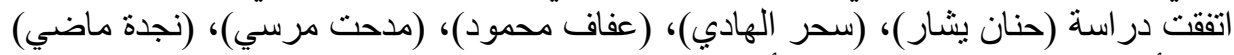

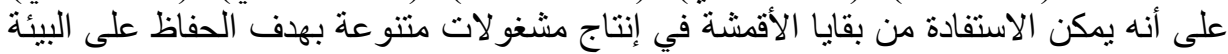

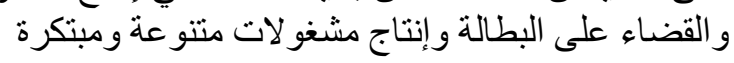




$$
\text { مجلة الاقتصاد المنزلى ـ مجلد Or ـ العدد الأول - } 10 \text { ـ ب م }
$$

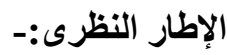

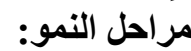

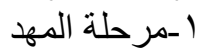

ب-مرحلة الحبو من سنة ألى سنتين

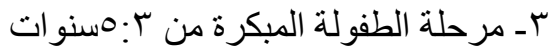

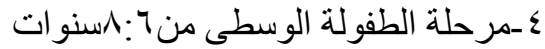

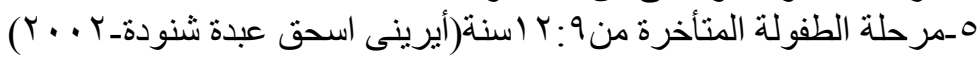

الألياف المستخدمة فى ملابس الأطفال:-

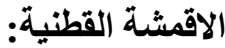

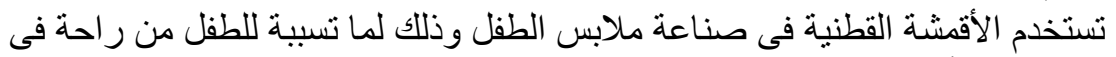

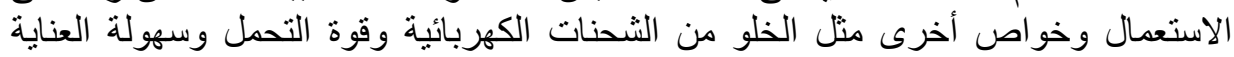
والمنانة وتعنبر الاقمشة القطنية من الخامات المناسبة لملابس الأطفال(علية أحمد عابدين

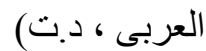

بعض المتطلبات الملبسية التى يجب مراعاتها في مرحلة الطفولة المبكرة:-

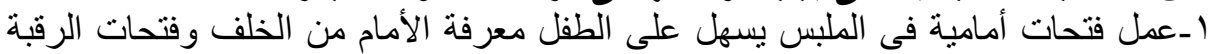

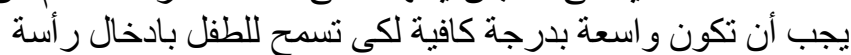

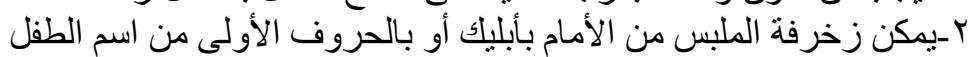

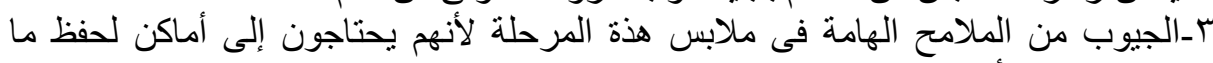
يجمعون من أنياء ع ـالسالوبيت من الملابس العملية للأطفال فى هذة المرحلة لأنها تسهل لهم الحركة وتوفر لهم

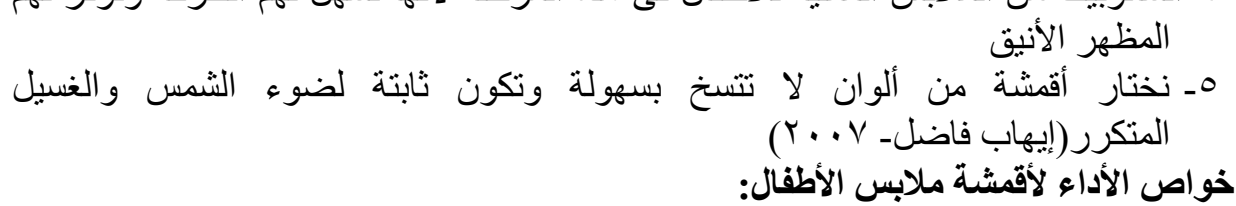

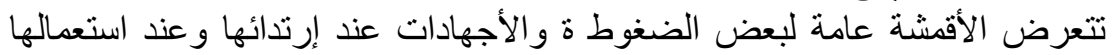

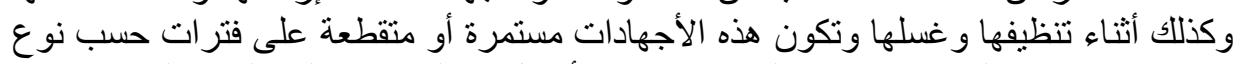

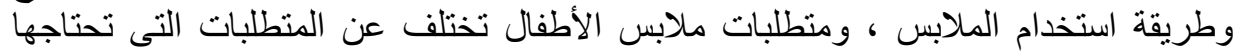

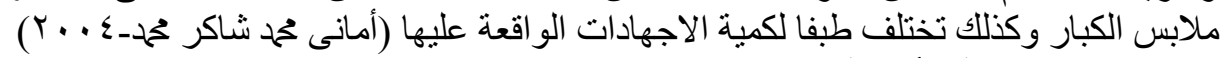

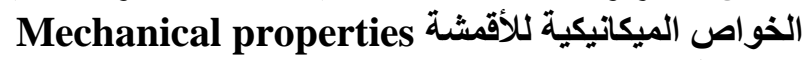

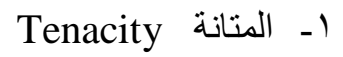
Elongation ت ب - الاستطالة

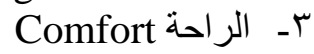

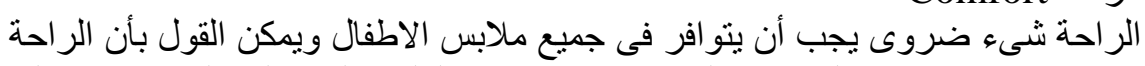

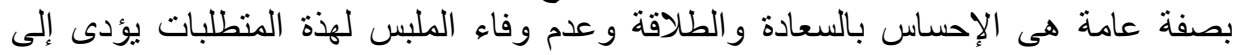

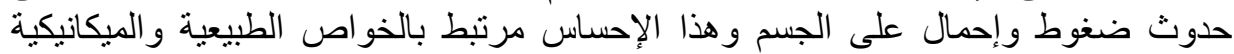

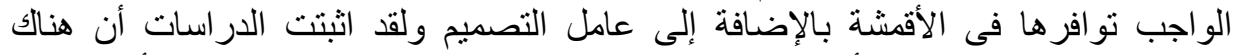

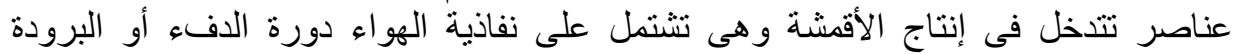




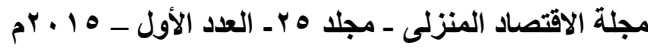
و التوصيل الحرارى أو حجز الرطوبة الممتصة والإقلال من الثحنة الأستاتيكية المتكونة

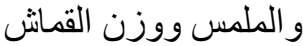
وتنقسم الراحة إلى نوعين(Kathryh.Hatch-1993)

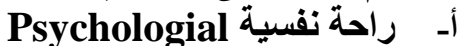

و هى تعبر عن مدى ملائمة الملبس للشخص نفسة و المناسبة المرتدى فيها الملبس

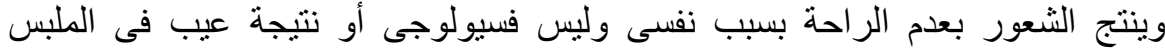

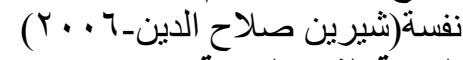

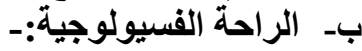

يعتبر موضوع الريولة احة بأبعادة المختلفة من الموضو عات المات المعقدة و المتعددة الأبعاد

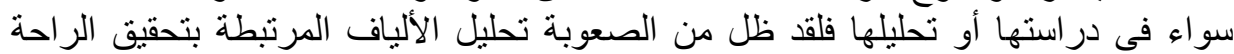

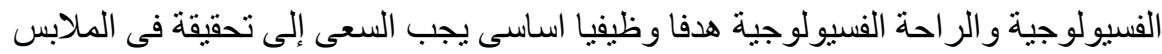
وتتقسم الر احة الفسيولوجية إلى نو عين:-

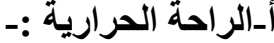

هى الر احة الناتجة عن التبادل الحر ارى و الرطوبى بين جسم الإنسان و الوسط المحيط بة

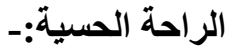

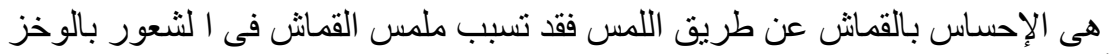

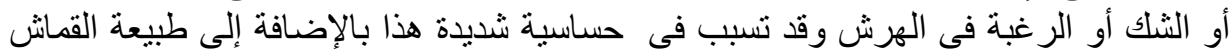

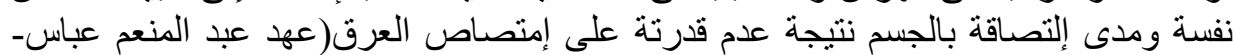

(Y...

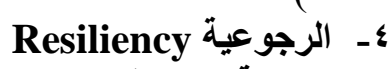

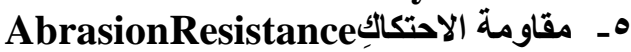

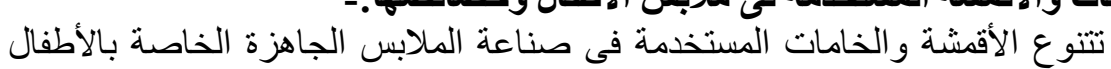

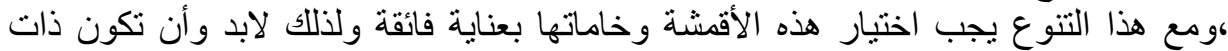

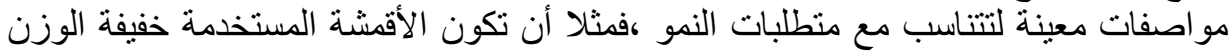

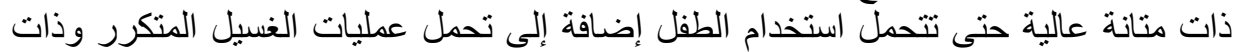

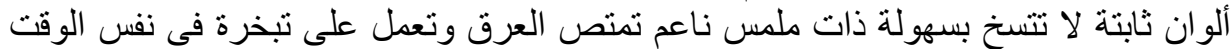

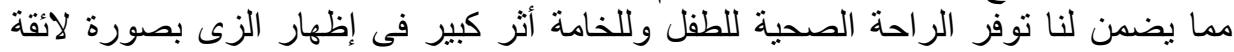

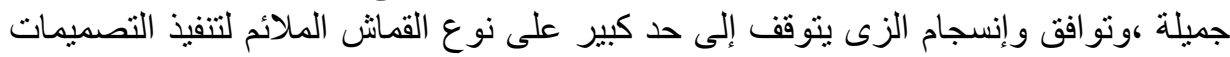

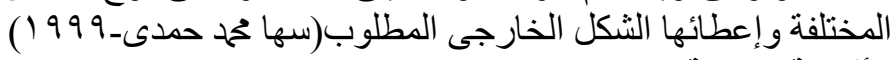

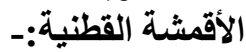

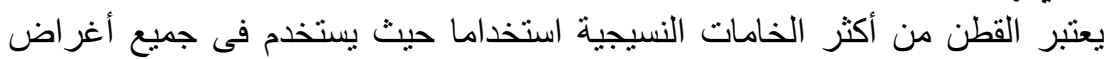

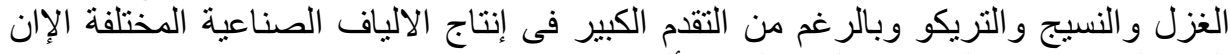
القطن لم يفقد مكان الصدارة بالنسبة لهذة الألياف

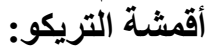

تعتبر صناعة التريكو أحد الصناعات النسيجية التى بدأت بالألياف الطبيعية ثم توسعت فى استخدام الألياف الصناعية وتنقسم أقمشة التريكو إلى نو عين التين 


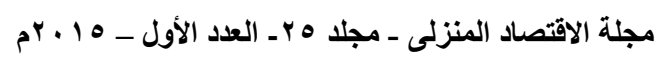

تريكو السداء

قماش نريكو ينتج من الغرز الرأسية بخيوط سداء والغرز الأفقية بتعانثق السداء مع

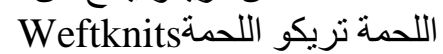

وينتج من خيط واحد يمر من جانب الماكينة على كل الإبر مكونا صفا أفقيا ثم يكرر

ذللك مرات منتالية مكونا تريكو اللحمة ويتميز بالليونةوينتج أيضا على الإبلى الماكينات الدائرية

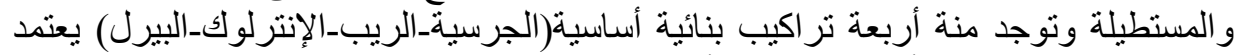

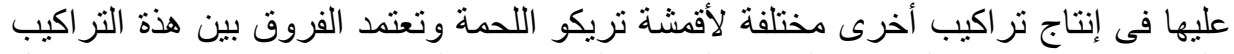

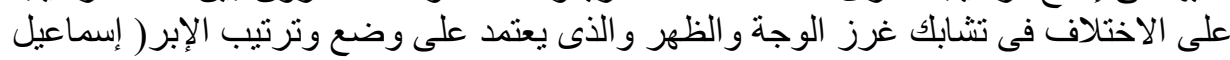

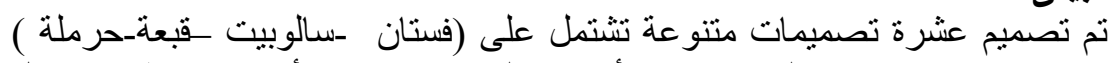

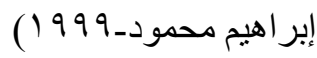

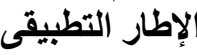

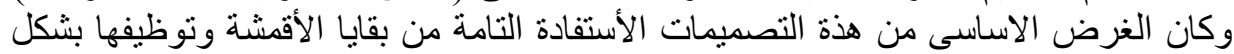

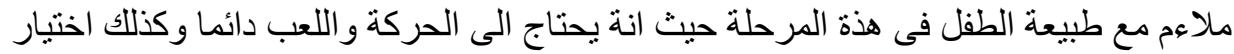

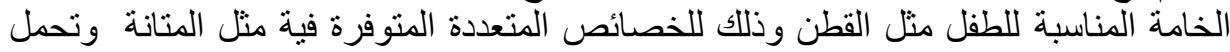

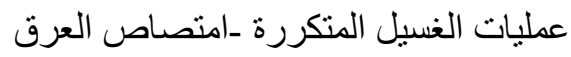
ـعمل تصميمات للاطفال من بقايا الاقمشة الفئة

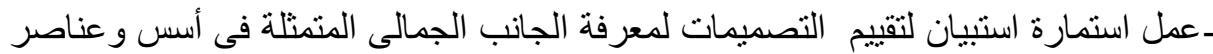

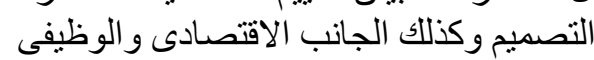

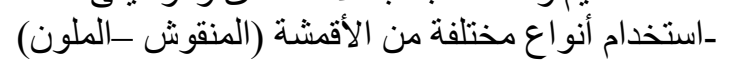

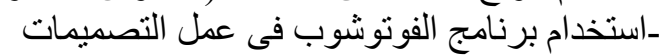

تصميم رقم (1)

\begin{tabular}{|c|c|c|}
\hline الموديل بمكملاتة & التحليل الوصفى & البيان \\
\hline & 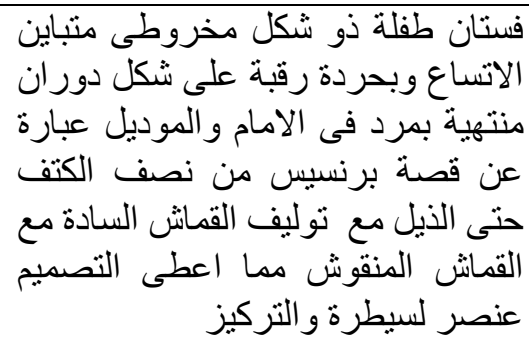 & للأسوديل الفنية \\
\hline & قماش قطن منقوش+قماش قطن سادة & المستخدمة \\
\hline
\end{tabular}

$\varepsilon 9$. 
مجلة الاقتصاد المنزلى ـ مجلد ه بـ العدد الأول ـ 10 • r م

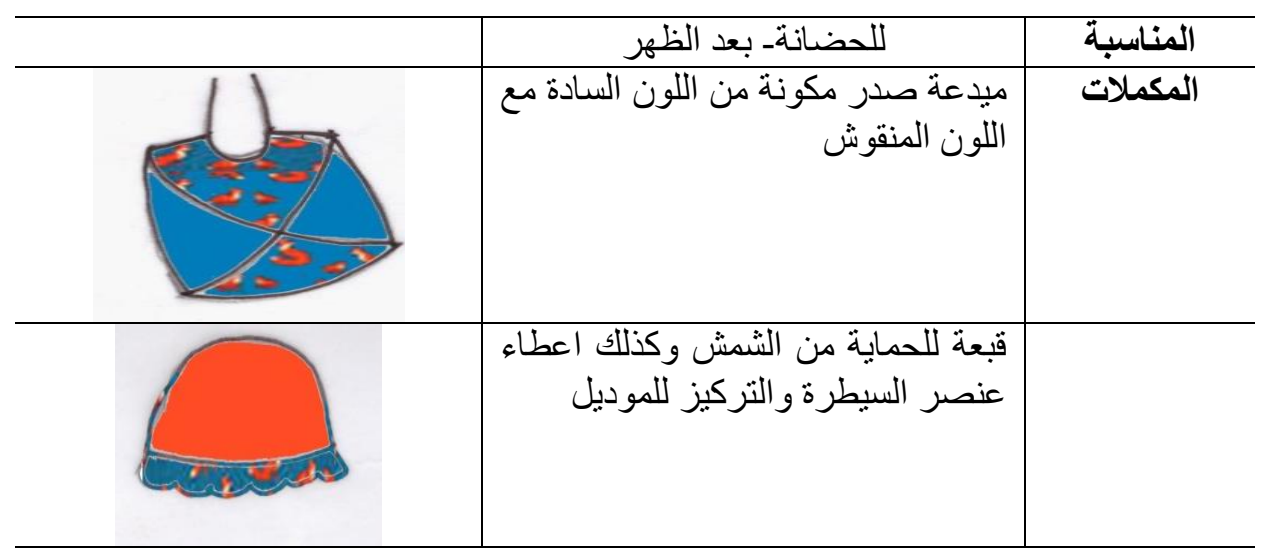

\begin{tabular}{|c|c|c|}
\hline \multicolumn{3}{|c|}{ تصميم رقم (Y) } \\
\hline الموديل بمكملاتة & التحليل الوصفى & 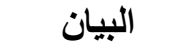 \\
\hline & 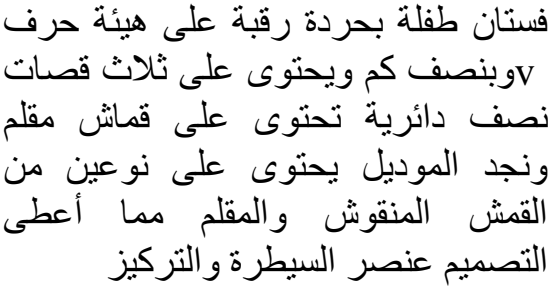 & الأسس الفنية \\
\hline & قماش قطن ملون+قماش قطن سادة & المستخدمة \\
\hline & للحضانة_ بعد الظهر & المناسبة \\
\hline & 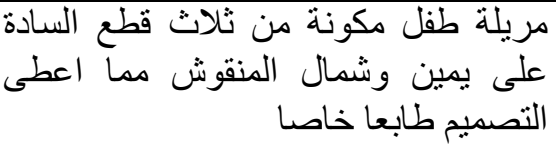 & المكملات \\
\hline & قبعة من قطع منتالية بين المنقوش والسمادة & \\
\hline & & \\
\hline
\end{tabular}


مجلة الاقتصاد المنزلى ـ مجلا هـ ـ العدد الأول ـ 10 ـ بم

تصميم (r)

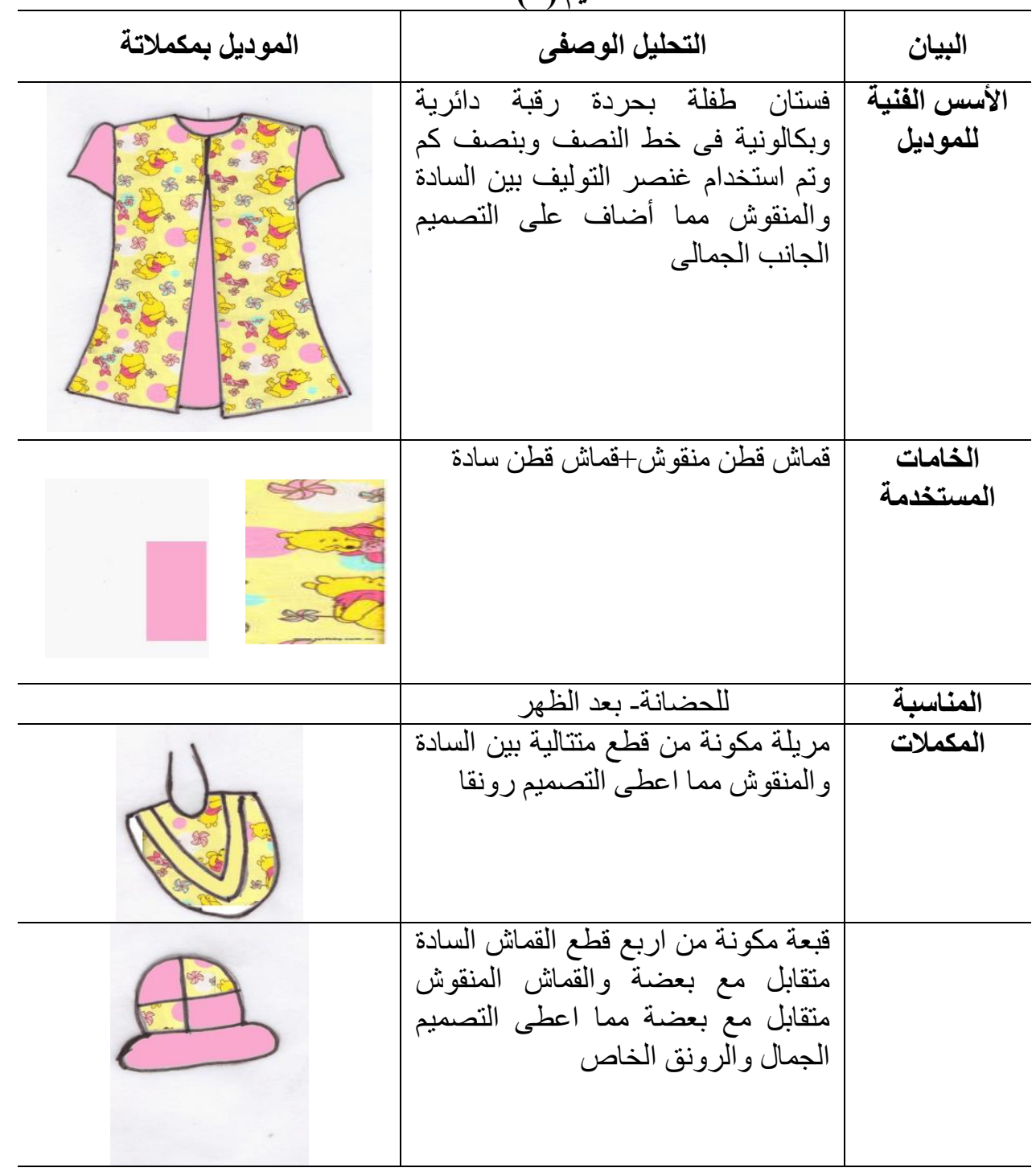




$$
\text { مجلة الاقتصاد المنزلى ـ مجلد } 0 \text { ــ العدد الأول - } 10 \text { ـ بم }
$$

تصميم (\&)

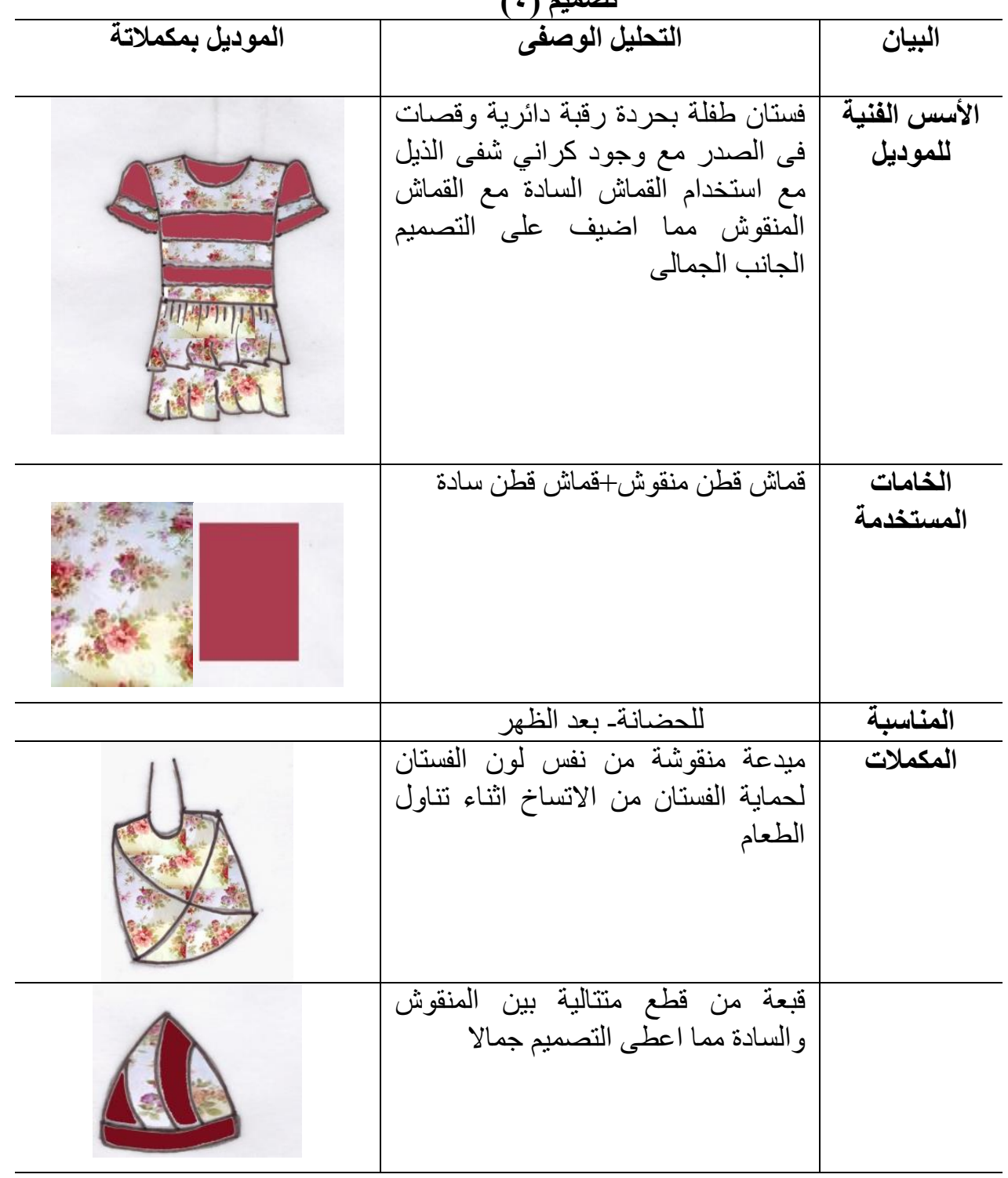


مجلة الاقتصاد المنزلى ـ مجلا هب ـ العدد الأول ـ 10 ـ r م

تصميم (ब)

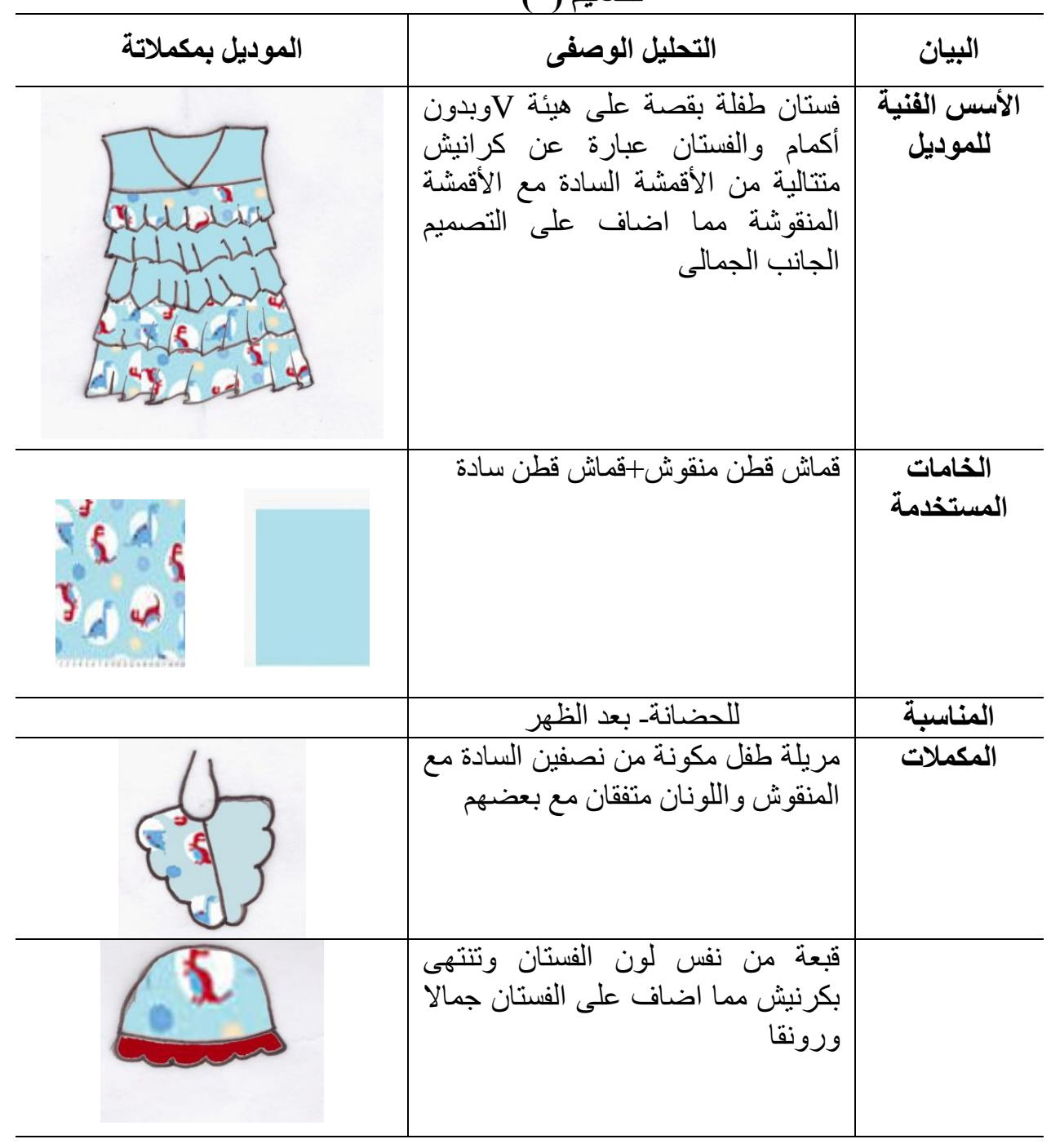


مجلة الاقتصاد المنزلى ـ مجلا هب ـ العدد الأول ـ 10 ـ ب م

تصميم رقم (1)

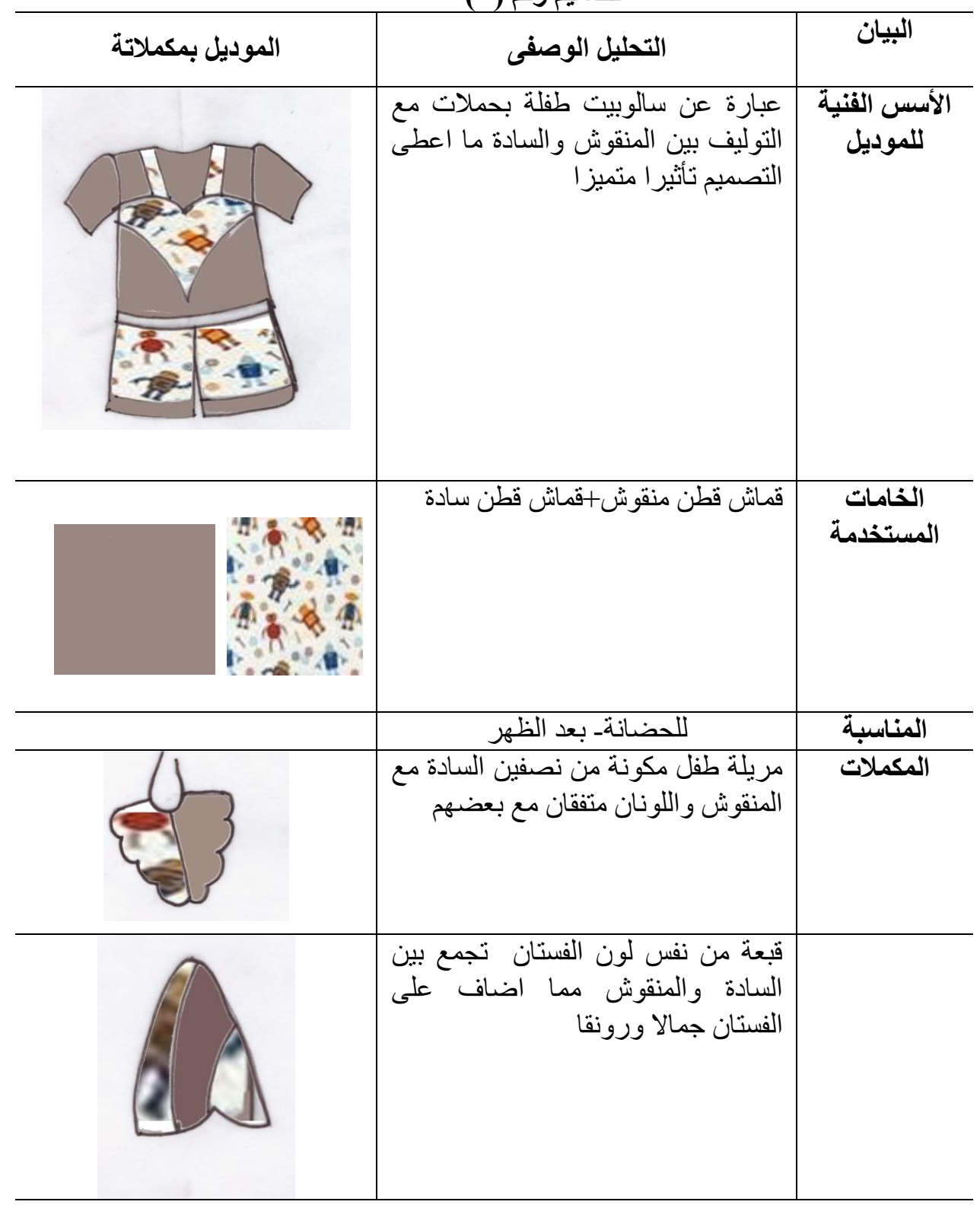




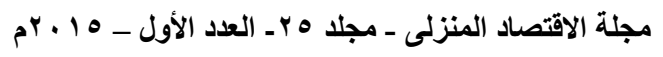

تصميم رقم (v)

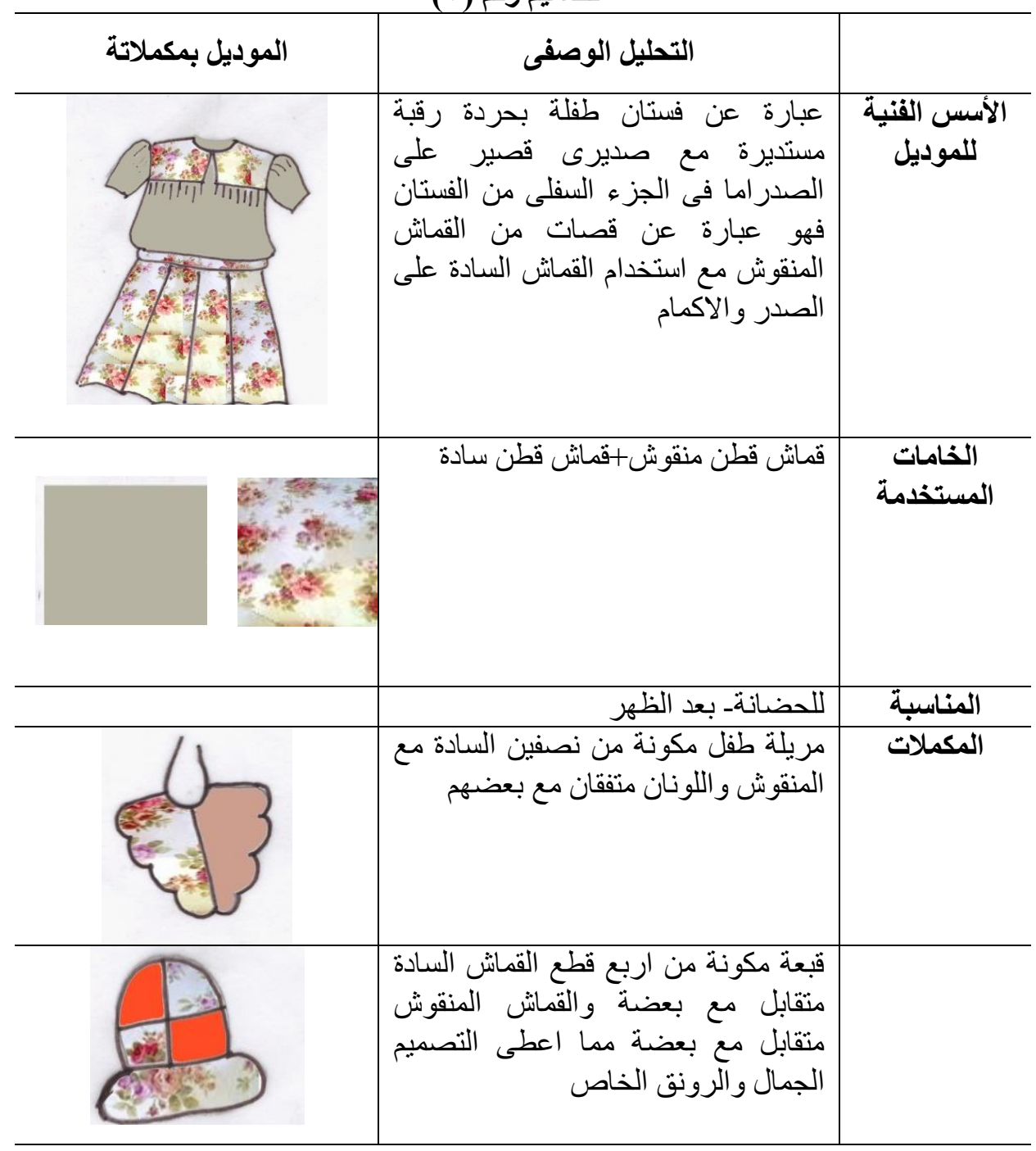


مجلة الاقتصاد المنزلى ـ مجلد هب ـ العدد الأول ـ 10 • بم

التصميم رقم (^)

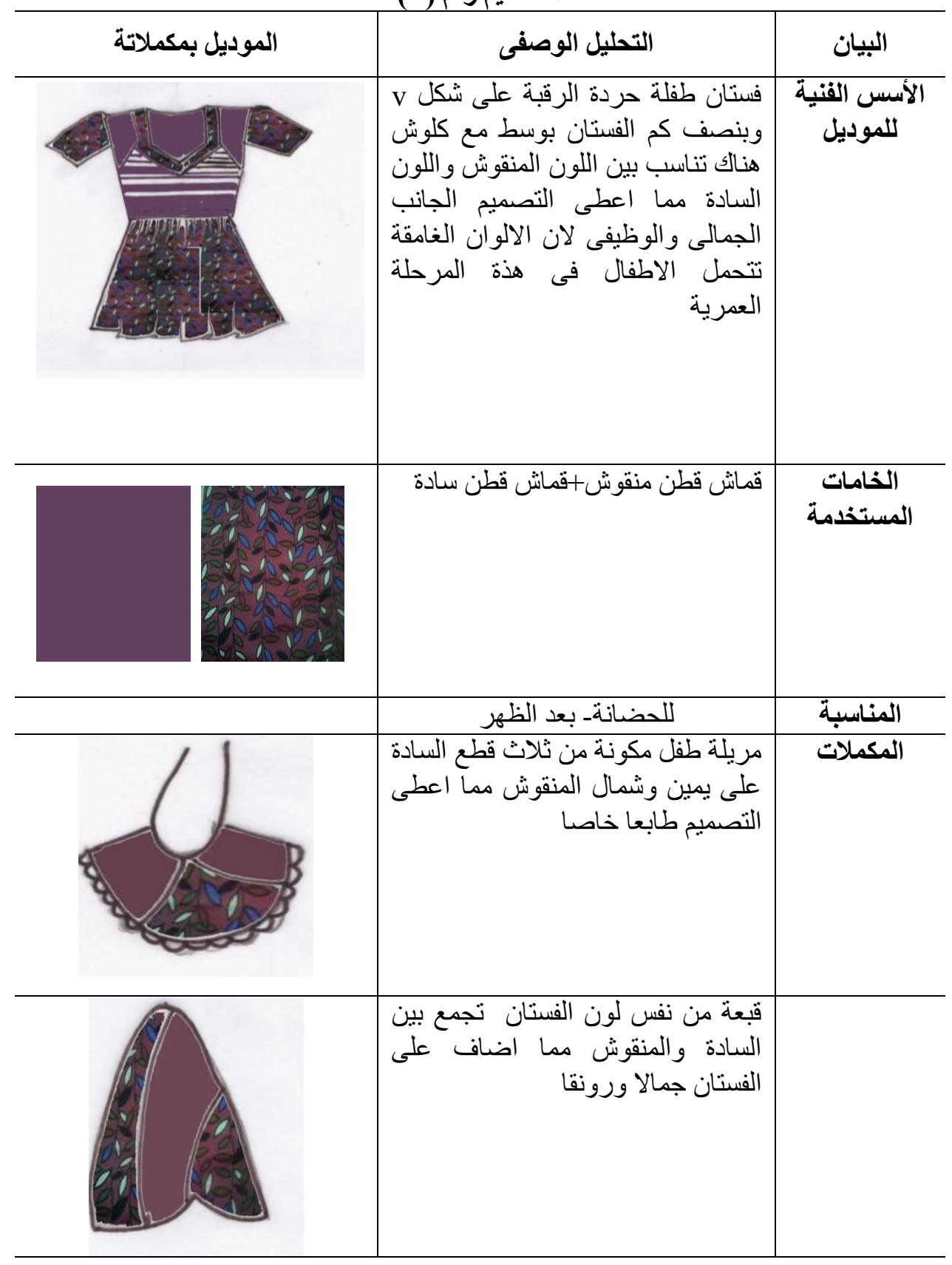


مجلة الاقتصاد المنزلى ـ مجلا هب ـ العدد الأول ـ 10 ـ ب م

تصميم رقم (9)

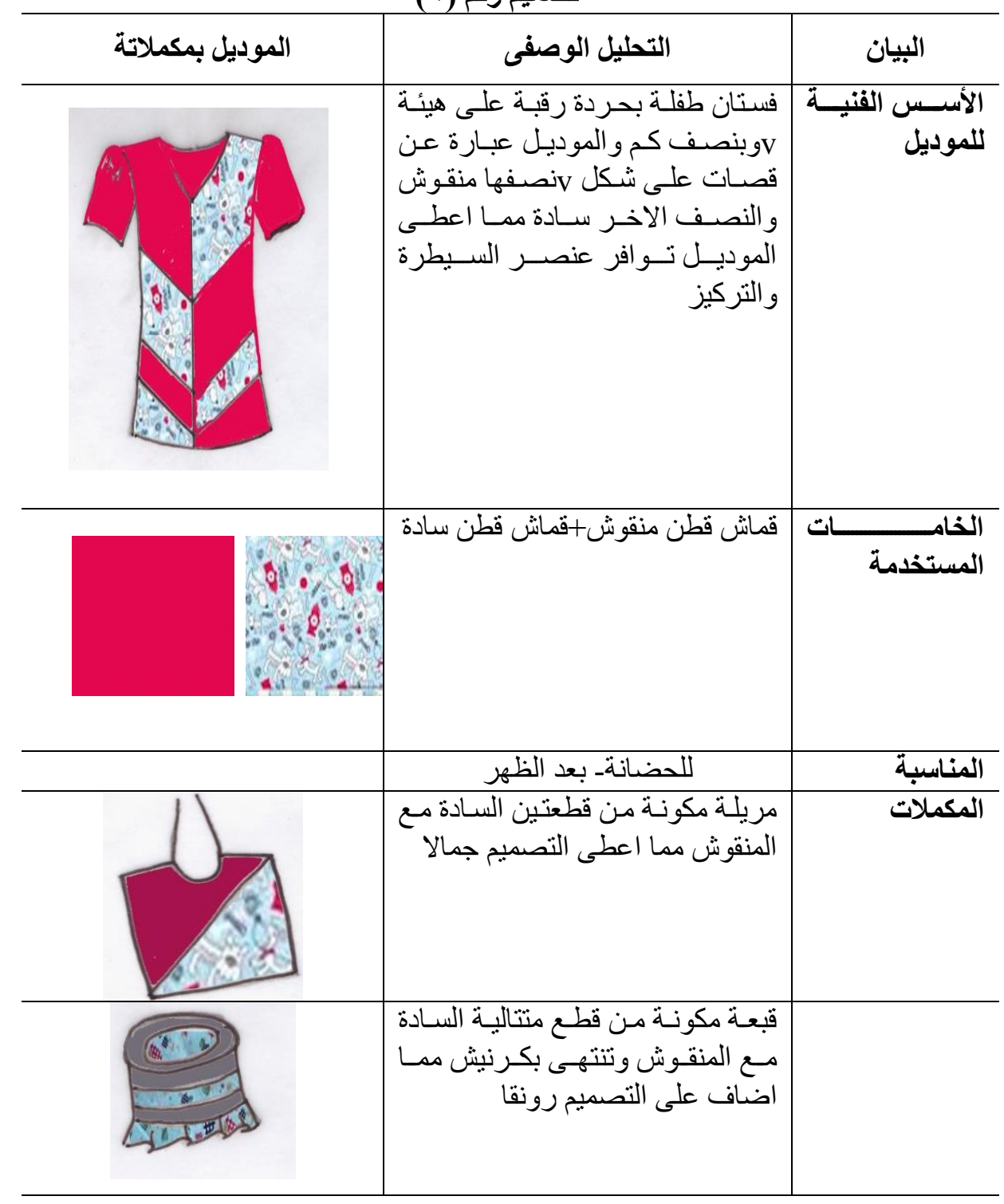




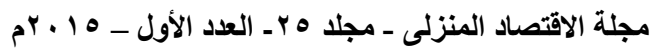

تصميم رقم (· (1)

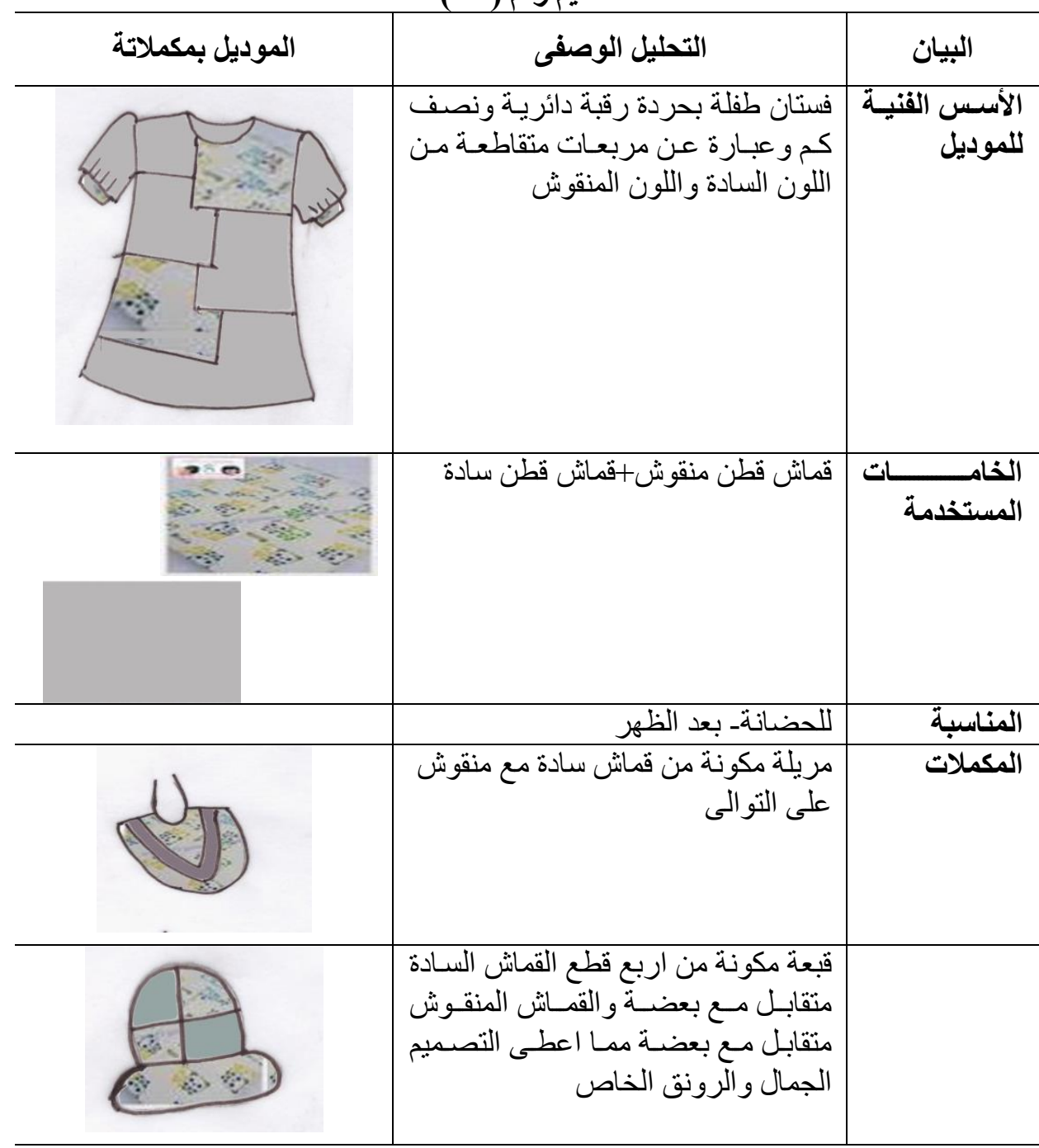

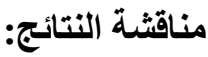

بعد الانتهاء مـن التصميمات المقترحة لملابس الاطفـال بمكملاتهـا تم عمل استتارة

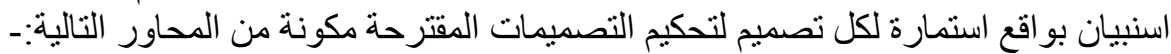

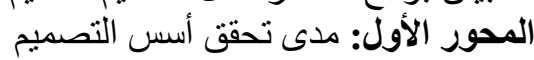

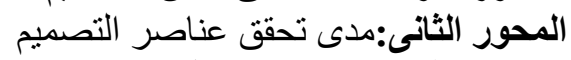
المحور الثالث:مدى ملائمة التصميمات لاستخدام بقايا الاقمشة 


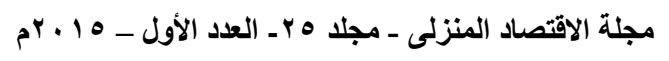

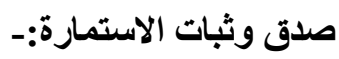

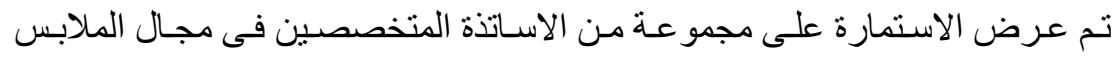

و النسيج للتحقق من صحة بنود الاستمارة وكانت صورة صورتها النهائت النية كما يلى:

تصميم رقم ( ) تصنون

\begin{tabular}{|c|c|c|c|c|}
\hline \multicolumn{3}{|c|}{ مستويات الأداء } & \multirow[b]{2}{*}{ 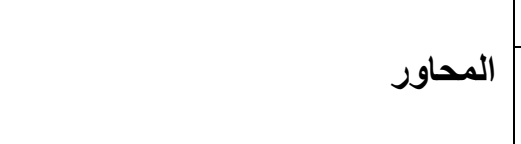 } & \multirow[t]{2}{*}{ 5 } \\
\hline غير مناسب & 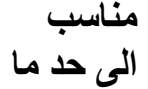 & مناسب & & \\
\hline & & & مدى تحقق أسس التصميم & \\
\hline & & & ج بـالـالاتزبية والتناسب & $\begin{array}{l}1 \\
-\end{array}$ \\
\hline & & & مدى تحقق عناصر التصميم & $r$ \\
\hline & & & خطوط التصميم مع طبيعة المرحلة & \\
\hline & & & | المرحلة العمرية للأطفال الملابس مع طبيعه & \\
\hline & & & 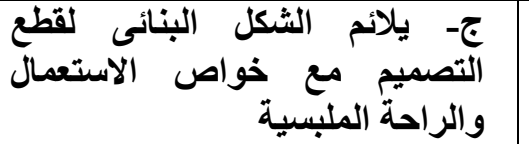 & \\
\hline & & & الد- مدىى ملائمة التصميم مع الخامة & \\
\hline & & & الاستخدام & $r$ \\
\hline & & & أل- مستلائمينة هذه التصميمات لاخل & \\
\hline & & & بالاحتياجات الملبسية لتلاطفال فيمي & \\
\hline & & & والتصميط المنفز & \\
\hline & & & لـى ملائمة التصميم مع بقابا الأقمشة & \\
\hline
\end{tabular}

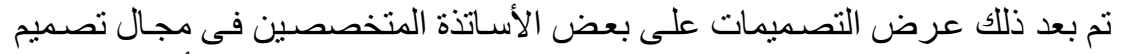

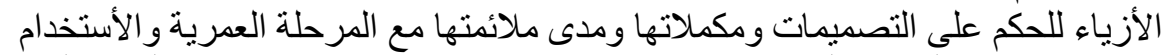

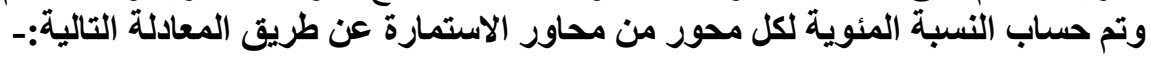

0. 


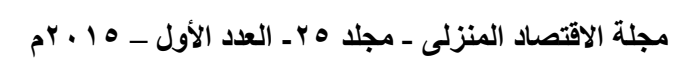

باعطاء (ع) درجة للمناسب ،و (؟) درجة للمناسب الى حد ما ،و ( ) درجة لغير مناسب،

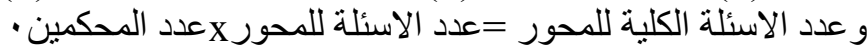

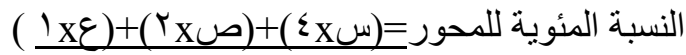

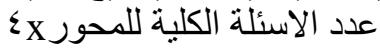

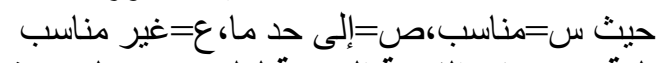

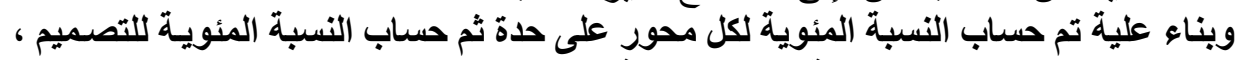

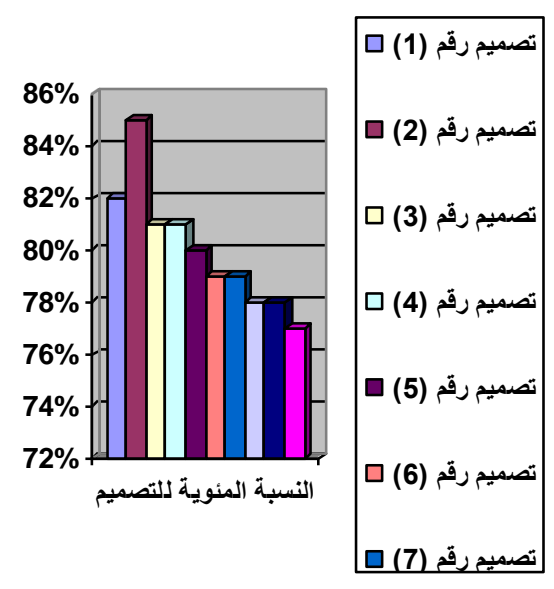

$$
\text { وحصلت التصميمات على النسبة المئوي التالية: }
$$

\begin{tabular}{|c|c|}
\hline اللتبنة المئوية & التصميمات \\
\hline$\% \wedge r$ & تصميم رقم (1) \\
\hline$\% \%^{\wedge \theta}$ & تصميم رقم (Y) \\
\hline$\% \wedge 1$ & تصميم رقم (r) \\
\hline$\% \wedge 1$ & تصميم رقم (ء) \\
\hline$\% \wedge$. & تصميم رقم (0) \\
\hline$\% \vee 9$ & تصميم رقم (") \\
\hline$\% \vee 9$ & تصميم رقم (V) \\
\hline$\% \vee \wedge$ & تصميم رقم (^) \\
\hline$\% \vee \wedge$ & تصميم رقم (9) \\
\hline$\% \vee V$ & تصميم رقم (· (1) \\
\hline
\end{tabular}

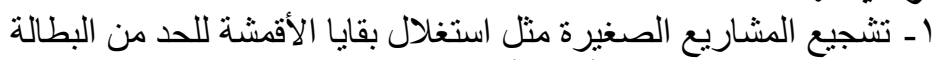

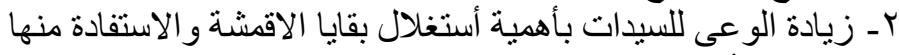

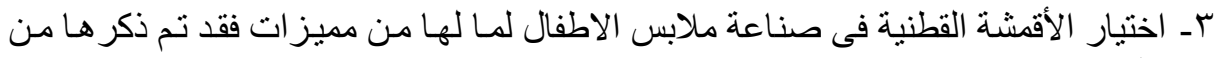

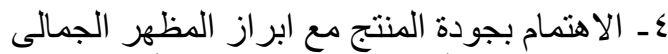

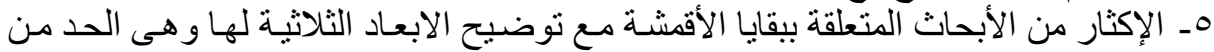

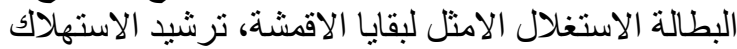

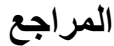

ا - إيمان رمضان محمود:تأثير بعض المو اصفات على خو اص الأقمشة ،رسالة ماجستير،كلية

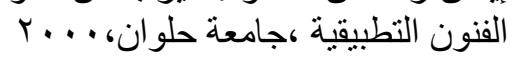

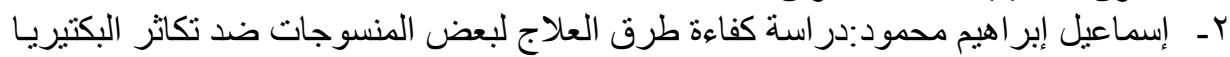

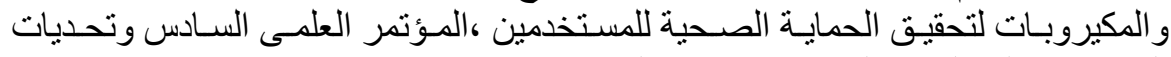

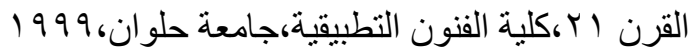

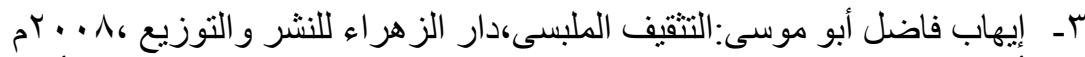

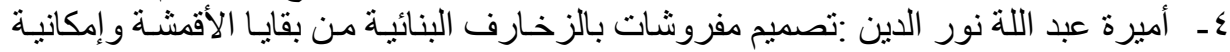

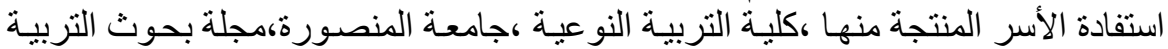

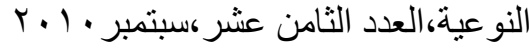




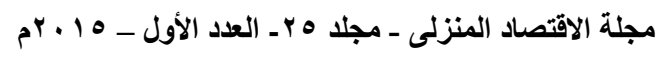

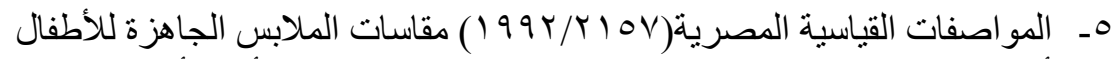

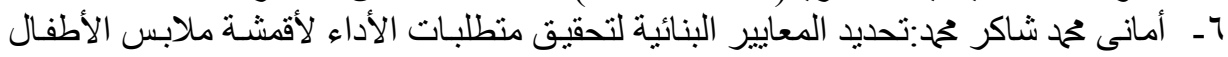

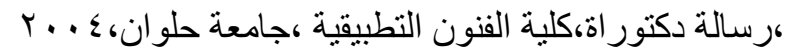

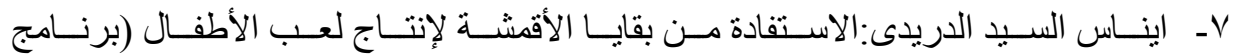

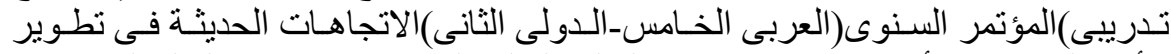

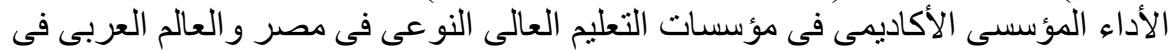

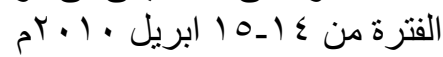

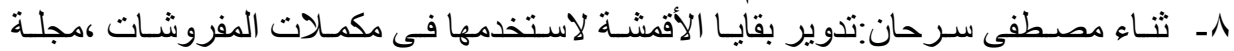

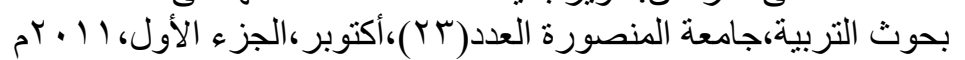

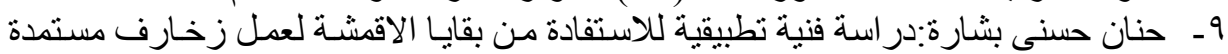

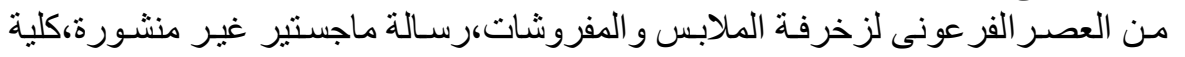

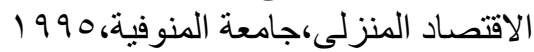

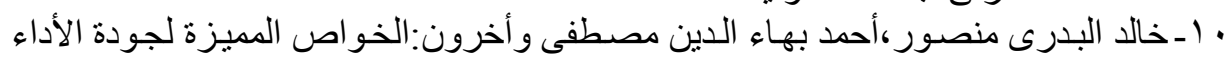

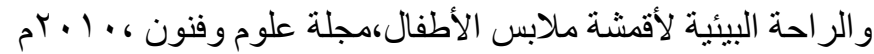

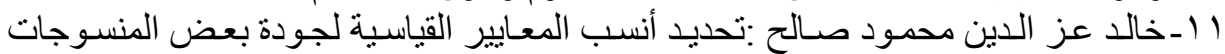

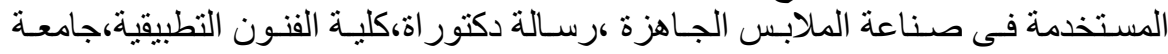

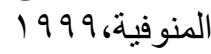

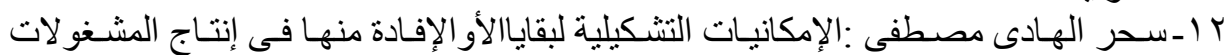

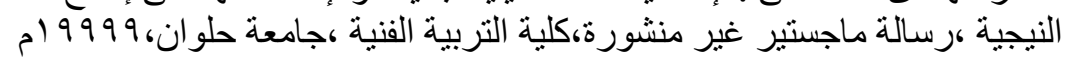

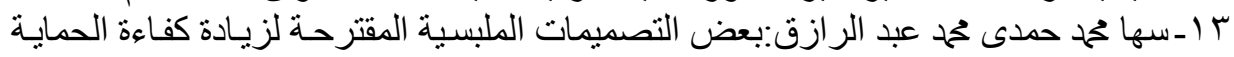

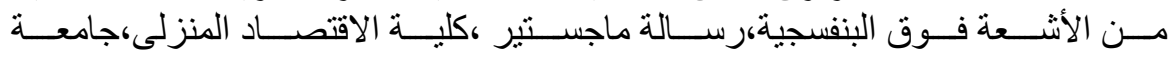

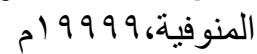
ـ ـ ـ شيرين صـلاحح الدين:در اسـة المتطلبـات الوظيفيـة لملابس الأطفال،رسـالة ماجستير ،كليـة

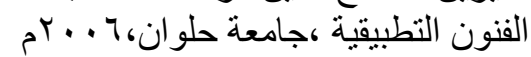

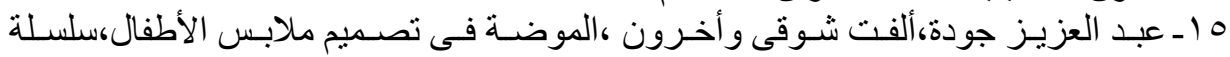

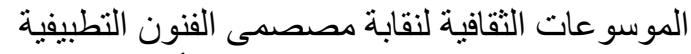

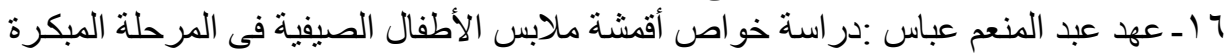

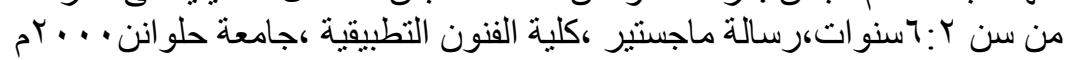

Kathryh.Hatch-Textile sciences west Publishing company --IV U.S.A.1993

1 ـ لمياء إبر اهيم أحمد عبد الفتاح:برنامج تدريبى لتأهيل الخريجيات لصناعة بعض مكملات

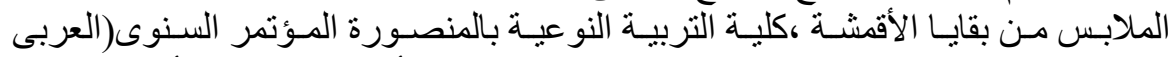

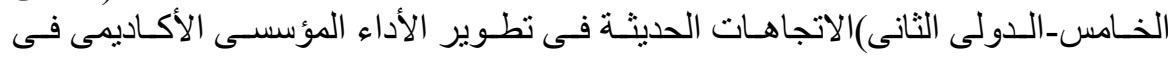

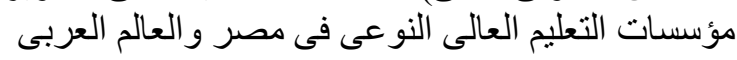

